\title{
A “de Soto Effect" in Industry? Evidence from the Russian Federation
}

\author{
Alexei Karas University College Roosevelt \\ William Pyle Middlebury College \\ Koen Schoors Ghent University
}

\begin{abstract}
The strengthening of land rights has been proposed as a policy to reduce financial market frictions and promote private investment in low- and middleincome countries. But assessments of these potential effects have proven inconclusive. One reason may be that research has focused on actors that face difficulties accessing credit for reasons other than the security of land tenure. We explore the effect of greater tenure security in a setting in which non-landrelated financial market frictions are apt to be mild-that is, among large urban industrial enterprises. Exploiting policy variation across Russian regions and firm-level survey data, we show that private land rights facilitate credit access and promote investment.
\end{abstract}

\section{Introduction}

Over the past 2 decades, the strengthening of land rights has become one of the most widely discussed policy prescriptions for reducing financial market frictions

Karas is a guest fellow at the Tjalling C. Koopmans Research Institute at Utrecht University's School of Economics. Pyle is a Leading Research Fellow at the International Center for the Study of Institutions and Development at the National Research University's Higher School of Economics, Russian Federation. Schoors is an affiliate Researcher at the Center for Institutional Studies at the National Research University's Higher School of Economics, Russian Federation, and was Research Fellow at the Bank of Finland's Institute for Economics in Transition (BOFIT) during the writing of this paper. We thank the following organizations for generous assistance in support of this project: the National Council for Eurasian and East European Research, the International Research and Exchanges Board, and the Bank of Finland Institute for Economies in Transition. The design and administration of the survey further benefited from the assistance and advice of many individuals and institutions, most particularly Irina Perova, Andrey Khakhalin, Gregory Kisunko, and the Levada Analytical Centre. We further thank seminar participants at Middlebury College; the Bank of Finland Institute for Economies in Transition; the University of Wisconsin's Center for Russia, East Europe and Central Asia; Ghent University; the Davis Center for Russian and Eurasian Studies; and the National Research University Higher School of Economics; participants at the 2013 International Society for New Institutional Economics conference in Florence; and Paul Dower, Erick Gong, and Paul Ruud for insightful comments and remarks.

[Journal of Law and Economics, vol. 58 (May 2015)]

(c) 2015 by The University of Chicago. All rights reserved. 0022-2186/2015/5802-0015\$10.00 
and promoting private investment in low- and middle-income countries. Land ownership, it is said, provides borrowers with an attractive form of collateral that can ease access to external finance. Moreover, by raising the cost of expropriation, it has the potential to provide those with land use rights greater assurance that a return can be realized on new investments. Though the logic here is not unreasonable, convincing empirical support has been elusive. But it is worth noting that research to date has concentrated on small-scale producers that inhabit environments that may lie beyond the frontiers of formal finance. The literature, that is, is devoid of studies focusing on actors in environments in which non-landrelated financial market frictions are apt to be less severe than those confronted by small-scale farmers and poor urban households. This article looks to fill that gap. We exploit a recent survey of large urban industrial enterprises in Russia and a quasi experiment occasioned by the country's postcommunist land reform to explore whether private land ownership increases access to finance and promotes investment.

Though Russia launched privatization rapidly in the 1990s, it followed a different path than many Central and Eastern European countries. Instead of simultaneously privatizing enterprise capital and land, Russia's privatization program applied only to equipment, buildings, and other structures. Land plots remained state owned. Largely for reasons of expediency, a fundamental principle of market economies - that the ownership of surface objects derives from ownership of the land underneath (superficies solo cedit) - was thus initially ignored. Today, however, the situation is different. A cursory study of Russia's contemporary urban landscape reveals a patchwork of tenure rights. As early as the mid-1990s and particularly since 2001, some regions have responded to federal initiatives by promoting the privatization of land, including land under otherwise-privatized industrial enterprises; others have proceeded much more slowly.

The relationship between land, on the one hand, and finance and investment, on the other, has been popularly associated with the Peruvian economist Hernando de Soto, who portrays the extension of widespread private land tenure (and the institutional infrastructure to support it) as a critical step in the development process. Indeed, he describes the inability of entrepreneurs to pledge fixed assets, notably land, over which they have user rights but not formal title as "the major stumbling block that keeps [the Third World and former Communist nations] from benefiting from capitalism" (Soto 2000, pp. 6-7). Though it has been skeptically received in some quarters, scholarly interest in this relationship-referred to recently as the "de Soto effect" (Besley, Burchardi, and Ghatak 2012) - has been appreciable (Woodruff 2001). But among sophisticated analyses that confront the potential endogeneity of land tenure, findings have been mixed. Besley (1995) presents evidence consistent with land rights being unrelated to credit access among Ghanaian farmers. Braselle, Gaspart, and Platteau (2002) find no systematic relationship between land tenure security and investment across household farms in Burkina Faso. And while Field (2005) and Galiani and Schargrodsky (2010) find that urban squatters in Lima and Buenos Aires, respec- 
tively, invest more in their properties after being granted formal tenure, their evidence suggests that increased access to credit is not primarily responsible. ${ }^{1}$

Is the de Soto effect a chimera? Do stronger rights over fixed assets (namely, land) neither improve access to credit nor increase investment? We find it plausible that the scholarship to date may have been too restrictive as to the settings in which these connections were explored. Indeed, as some of the authors of the above-noted studies themselves observe, non-land-related factors may explain the weak connection between land rights and credit access. That is, regardless of whether or not they have title to their land, the farmers and poor urban households that have received scholarly attention may face other barriers-for example, scale and location - that limit their access to lenders who, all else equal, would value titled immovable assets pledged as collateral. The same concerns cannot be said to apply to the urban industrial firms that are our focus here.

In the following, we first demonstrate the hypothesized correlations between land tenure, on the one hand, and credit access and investment intensity, on the other. Surveyed firms, that is, that own their land report both greater ease in accessing credit and more intense investment activity. These relationships remain robust to a wide variety of firm-specific and regional controls, including regional fixed effects. While consistent with a de Soto effect, these associations are not interpretable as such given that land tenure may be endogenous. We address that possibility here, in part, by exploiting the aforementioned policy variation across Russia's territorial units. Some firms happen to be in regions in which the "price" for privatizing urban land is low; and some happen to be in regions in which the price is high. Using a proxy for these policy differences to instrument for the current tenure status of surveyed firms' primary production plots-thereby identifying a local average treatment effect-we continue to observe that firms that own their land have both greater access to capital and more intense investment agendas.

Though our instrumental variables (IV) strategy mitigates concerns that the relationship between land rights and access to finance is driven by reverse causation or omitted firm-level variables, regional land policy may be correlated with relevant regional characteristics. Regional land policy, that is, may itself be endogenous. We respond to this concern in three ways. First, we demonstrate that the correlations of interest survive the inclusion of regional fixed effects. Second, our IV models include a rich set of regional controls plausibly related to firms' access to finance and investment activity. Third, we explore deeper, historical drivers of our instrument. Postulating that regional policy reflects both supply and demand forces unleashed by postsocialist economic and political liberalization, we isolate several variables whose values in 1995 explain a substantial share of the variation in the trajectory of regional land policy over the entire reform period. Acknowl-

\footnotetext{
${ }^{1}$ Field and Torero (2008) find that an urban titling program in Peru did not increase commercial lending. Others who have looked at land rights and credit in the context of the more general question about investment activity include Alston, Libecap, and Schneider (1996) and Do and Iyer (2008).
} 
edging the nonrandom nature of regional policy enables us to contribute to the literature on the political economy of privatization by presenting evidence consistent with high land rents-as captured by regional urbanization rates and per capita income-making public officials less prone to privatize assets under their control. And controlling for these policy supply factors, we demonstrate that the demand for urban land privatization-as measured by industrial output per capita and the percentage of loss-making enterprises-further explains policy in a predictable manner. Finally, in addition to the regression results consistent with a de Soto effect in industry, we demonstrate with direct survey responses that firms' managers believe land to be an important source of collateral to secure external loans. For instance, nearly half of the surveyed firms that took ownership over their land plots cited improved access to external financing as an extremely important motivation.

We elaborate on all of this evidence in the rest of the article. Section 2 lays out changes in the policies governing Russia's nonagricultural commercial lands and highlights the persistence of interregional policy variation. Section 3 introduces a unique survey of large urban industrial enterprises. In Section 4, we explore conditional correlations between the tenure status of enterprises' primary production plot, on the one hand, and their ease in accessing credit and the intensity of their investment activity, on the other. In Section 5, we deploy a measure of regional policy variation as an instrument to mitigate concerns about reverse causation and firm-level omitted variables. In recognition of the fact that this regional policy variation may itself be endogenous, Section 6 explores its historical determinants, which allows us to contribute, in a small way, to the literature on the political economy of privatization. Section 7 provides additional robustness checks and exploits the survey further to demonstrate that the respondents themselves believe in a de Soto effect. Section 8 concludes.

\section{Land Policy at the Federal and Regional Levels}

Issues surrounding land tenure seem to have been all but forgotten in commentary on the privatization of Russian industry. ${ }^{2}$ This is odd. Considering the centrality of industry to Soviet-era urban development, some of the choicest real estate in Russia's largest cities is given over to industry (Bertaud and Renaud 1997). Further, given the noncompetitive technologies in use at many Soviet enterprises on the eve of market-oriented reforms, land likely accounted for a substantial share of enterprise asset value when privatization was launched in the early 1990s. Very few commentators on Russia's privatization, however, have paid attention

\footnotetext{
2 This section draws on Khakhalin and Pyle (2009). For examples of the omission of land tenure from the literature, see any of the Russia-focused empirical studies referenced in the widely cited literature review of Estrin et al. (2009). Even though several speculate as to why privatization seems not to have produced the desired results in Russia, none note the potential role of the ambiguous rights over land.
} 
to the split of ownership rights over the complementary land and capital assets or thought to attribute the slow pace of industrial restructuring to it. ${ }^{3}$

Bucking centuries of tradition, Russia's 1993 constitution enumerated a right to private land ownership. But subsequent efforts to give specific form to that language-including presidential decrees, chapters in the civil code enacted in 1994 and 1995, and disparate pieces of legislation-produced a body of law that was seen as "incomplete... and sometimes ambiguous" (O'Leary and Kaganova 1997, p. 8). ${ }^{4}$ Nevertheless, between 1994 and 1997, an estimated 34,500 hectares, across roughly 50 Russian federal subjects, were transferred to private enterprises. ${ }^{5}$ In May 1997, a new presidential decree granted regional administrations nearly full discretion in establishing land sale prices. Thereafter, land prices began to vary significantly across Russia, and the overall pace of enterprise land privatization slowed (Kaganova 1998; Limonov, Oding, and Vlasova 2001). Since subfederal administrations were given greater control to set lease rates on stateowned land than tax rates on enterprise-owned land, they had an incentive to make land privatization procedures complex, expensive, and time consuming. In 32 regions, land privatization was banned by laws that contradicted federal legislation, by popular referenda, or by provisions added to the region's constitution. Moscow's Duma, for instance, passed a resolution that land plots occupied by privatized enterprises could be leased but not sold.

Most privatized enterprises initially held the lands they occupied under the right of permanent (perpetual) use (PPU), a Soviet-era form of land tenure that grants its holder a right to use and build on a parcel but not to dispose of it through, for instance, sale to another party. This form of land tenure, reenumerated in the Russian Civil Code of 1995, was characterized as permanent only because a termination date was not specified. If the government did dispossess a PPU holder of its lands, it faced a legal obligation to provide compensation at market value.

A breakthrough in the enterprise land privatization process occurred in 2001 when the Putin administration successfully pushed the Russian Federation Land Code through the national legislature. Designed to reinvigorate the process begun in the mid-1990s, it laid out mechanisms to force divestiture of state lands under privately owned structures and to unify titles to land and buildings. For instance, it called for the ownership of real estate objects to henceforth follow ownership of the attached land plot, granted exclusive right to purchase or lease state-owned land to the owner of the attached real estate object, gave to private

\footnotetext{
${ }^{3}$ Exceptions to this rule include Boycko, Shleifer, and Vishny (1995), Heller (1998), and Lewis et al. (1999).

${ }^{4}$ Presidential Decree 1535, issued in July 1994, spelled out procedures for acquiring the lands underneath privatized, nonagricultural enterprises. In conjunction with a 1995 decree that reduced the purchase price of enterprise-occupied land, it paved the way for a number of privatized enterprises to take ownership of their land plots.

${ }^{5}$ This article uses the terms "Russian federal subjects" and "regions" interchangeably. The Russian Federation comprises more than 80 federal subjects (including Moscow and St. Petersburg), each with equal representation in the Federation Council.
} 
owners of buildings on land plots owned by other private parties the preemptive right to purchase the land, and prohibited the future privatization of real estate objects without the concurrent privatization of the attached plot (Remington 2002; World Bank 2006).

Perhaps most notably, the land code sought to bring an end to the right of PPU by requiring private enterprises to convert from the Soviet-era form of land tenure to rights of ownership or lease by January 1, 2004. Further, the upper bound limiting the price that regional administrations could charge for enterprise land was reduced, and their land sale legislation was to be brought into line with federal law. Although this legislative push did lead to an increase in the reregistration of enterprise land rights in many regions, its impact was not as great as anticipated. In an effective capitulation to the resistance the new provisions were encountering, the original deadline for converting rights of PPU was first pushed back 2 years to 2006, then again to 2008, and finally to the summer of 2012 .

The response of subfederal jurisdictions to the 2001 land code has varied tremendously. In some municipalities, a substantial share of land-including parcels that were unimproved and those under privatized enterprises-was sold to the private sector; in others, such as Moscow, the municipal government retains an effective ownership monopoly (Kisunko and Coolidge 2007; World Bank 2006). More recently, the long-awaited Federal Law 212 enacted in July 2007, Major Amendments to Land Privatization Legislation, seemed to hold out the promise of resolving, once and for all, ambiguities surrounding the ownership of enterprise land. But many local administrations continue to put up resistance. Although Federal Law 212 laid out a new mechanism for establishing the purchase price of plots, requiring that it not exceed 2.5 percent of the cadastral value (20 percent in Moscow and St. Petersburg), evidence suggests that some regions responded by rather capriciously increasing cadastral values so as to discourage land purchases. Regional and municipal governments have also maintained an array of formal and informal barriers to limit competitive access to previously unused urban parcels. ${ }^{6}$ The business press continues to be filled with stories of how some region-level bodies attempt to undermine the intent of federal land legislation (Vasilieva 2011; Yel'kina 2011; Interfax 2011).

Regional officials, in other words, have effectively been able to manipulate the price for privatizing a hectare of urban land. When given the discretion, as in the 1990s, they have done so explicitly and directly (Kisunko and Coolidge 2007). At other times, when their policy autonomy has been more circumscribed in a formal sense, some have tinkered with the price indirectly by arbitrarily raising the cadastral values that serve as the basis for a plot's price. They also have been able to raise prices implicitly by putting various bureaucratic obstacles in the way of

\footnotetext{
${ }^{6}$ One analysis suggests that the inability to access land on transparent terms constitutes as big an obstacle to business development in Russia as anywhere in the world (Muir and Shen 2005). Among Russian enterprises that have direct experience with them, difficulties in acquiring land are more problematic than issues concerning bribery, the courts, or access to finance, all matters that tend to receive more attention (World Bank 2006). Similar results have been found in research focusing on the barriers to small businesses' development (Zhuravskaya et al. 2005).
} 


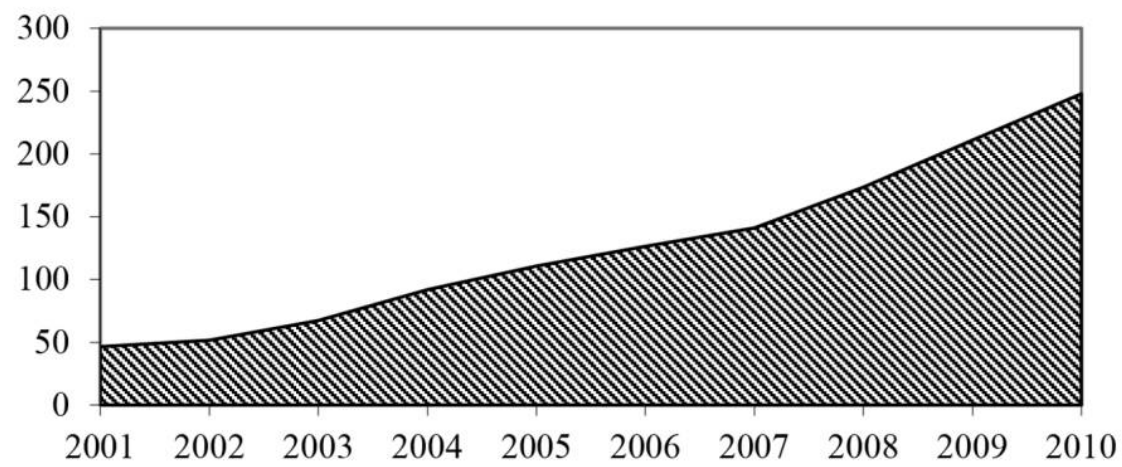

Figure 1. Land held privately by firms in urban settlements (1,000s of hectares)

firms. Regardless of the mechanisms used, this regional variation in the price can be seen as exogenous to the decisions of individual firms.

The reforms set in motion over the past 2 decades have been such that industrial enterprises have operated under one of three land tenure regimes. Some have formal private title to their land; some lease, making regular rental payments to government agencies; and yet others continue to occupy their land under the old Soviet-era framework of PPU. As of January 2010, in urban settlements, private firms owned 247,800 hectares, compared to 7,108,000 held by the state and municipalities. Since the passage of the 2001 land law, this relationship between private and state lands has changed dramatically; the ratio of the former to the latter has grown at roughly 18 percent per year, on average. ${ }^{7}$ Figure 1 captures the sixfold increase from 2001 to 2010 of land owned by private enterprises in urban settlements (Gosudarstvennyi doklad 2001-10).

As suggested above, the national-level data mask a great deal of variation in the pace of nonagricultural land privatization across regions in Russia. Comprehensive data on land ownership at the level of Russia's 80-plus territorial subjects is difficult to obtain. By far the most complete source of data on regional land stocks that we have uncovered was made available by the Federal Agency for the Real Estate Cadastre (Roskadastr); these data address stocks as of January 1, 2008. Similar data from earlier years were not, to our knowledge, ever made available. In March 2009, the agency was subsumed by the Federal Service for Registration, Cadastre, and Cartography (Rosreestr). ${ }^{8}$ Of the 7,875,500 hectares of land in urban settlements, the Roskadastr data designated roughly 45 percent $(3,512,200$

\footnotetext{
${ }^{7}$ With regard to enterprise land alone, the first decade of the 20th century could be described as one of rapid privatization, a characterization much at odds with the standard story that in Putin's Russia, privatization stalled and the share of Russia's gross domestic product produced by private enterprise fell (Aslund 2007, p. 251).

${ }^{8}$ The Roskadastr web site was the source for the comprehensive regional data. After Roskadastr was subsumed by Rosreestr, the site was no longer available.
} 
hectares) as residential, commercial, or industrial (RCI) land. ${ }^{9}$ Of Moscow's 109,100 hectares, for instance, roughly 77 percent were so described, as were half of St. Petersburg's 139,900 hectares. ${ }^{10}$

In the absence of any indicators that describe the uses of land more finely, we interpret the ratio of urban RCI land owned by enterprises to that owned by government entities as a good measure of the pace and extent of urban industrial land privatization in a particular region. Below we present evidence that this index of urban industrial land ownership is a good proxy for the policy orientation of Russia's federal subjects vis-à-vis land reform. Table 1 lists the index by territorial subject and the number of enterprises located in each that participated in the survey discussed below.

\section{Survey of Large Urban Industrial Firms}

To understand the effects of industrial land privatization, we collaborated with Moscow's Levada Analytical Centre to design and administer a survey of 359 large urban industrial enterprises in the fall of 2009. To focus on firms likely to operate on large plots of land, we addressed only those that had at least 500 employees in 2007. We also restricted our analysis to former state-owned enterprises that had been founded prior to 1986 but privatized prior to 2004. By design, roughly half of the firms were from regions with more progressive policies vis-à-vis urban land (that is, in the top third of the regions in Table 1). Just under one-fifth of the firms were in either Moscow or St. Petersburg, Russia's two largest cities. The rest were distributed relatively equally across cities (each a capital of a territorial subject) of three different size ranges: 1-3 million, .5 million-1 million, and .25-.5 million people. In all, the respondents represented 53 territorial subjects. ${ }^{11}$

Respondents answered general questions regarding their firm and questions specifically addressing land-related issues. A series of questions addressed the firm's primary production plot, with separate blocks for firms that owned the plot privately $(N=172)$, those that leased it $(N=131)$, and those that held it under the right of PPU $(N=56)$. Table 2 presents characteristics of the firms.

All respondents were asked to assess, on a scale from 1 to 5 , how problematic difficulties in accessing credit are for their operations (with 1 representing "not at all" and 5 "extremely problematic"). As shown in Table 2, firms that hold

\footnotetext{
${ }^{9}$ Formally, Roskadastr's designation encompasses "lands for residential and commercial structures as well as lands for industry, transport and communications" (table 9.1, Lands for Residential and Commercial Structures, Lands for Industrial and Public Use as Well as Transport and Communications, and Lands for Other Special Purposes; our translation from the now-defunct Roskadastr website).

${ }^{10}$ In the Russian capital, a good amount of land is given over to parks and largely undeveloped green spaces; within the city limits of St. Petersburg, roughly 20,000 hectares are designated as arable agricultural land.

${ }^{11}$ Of those firms contacted to participate in the survey, 429 refused categorically, 308 did not refuse outright but did not end up participating for one reason or another (for example, the surveying organization had some difficulty in settling on a mutually convenient time), and at 42 firms the necessary respondent was absent (for example, because of illness or vacation). These response rates are in no way correlated with regional land policy.
} 


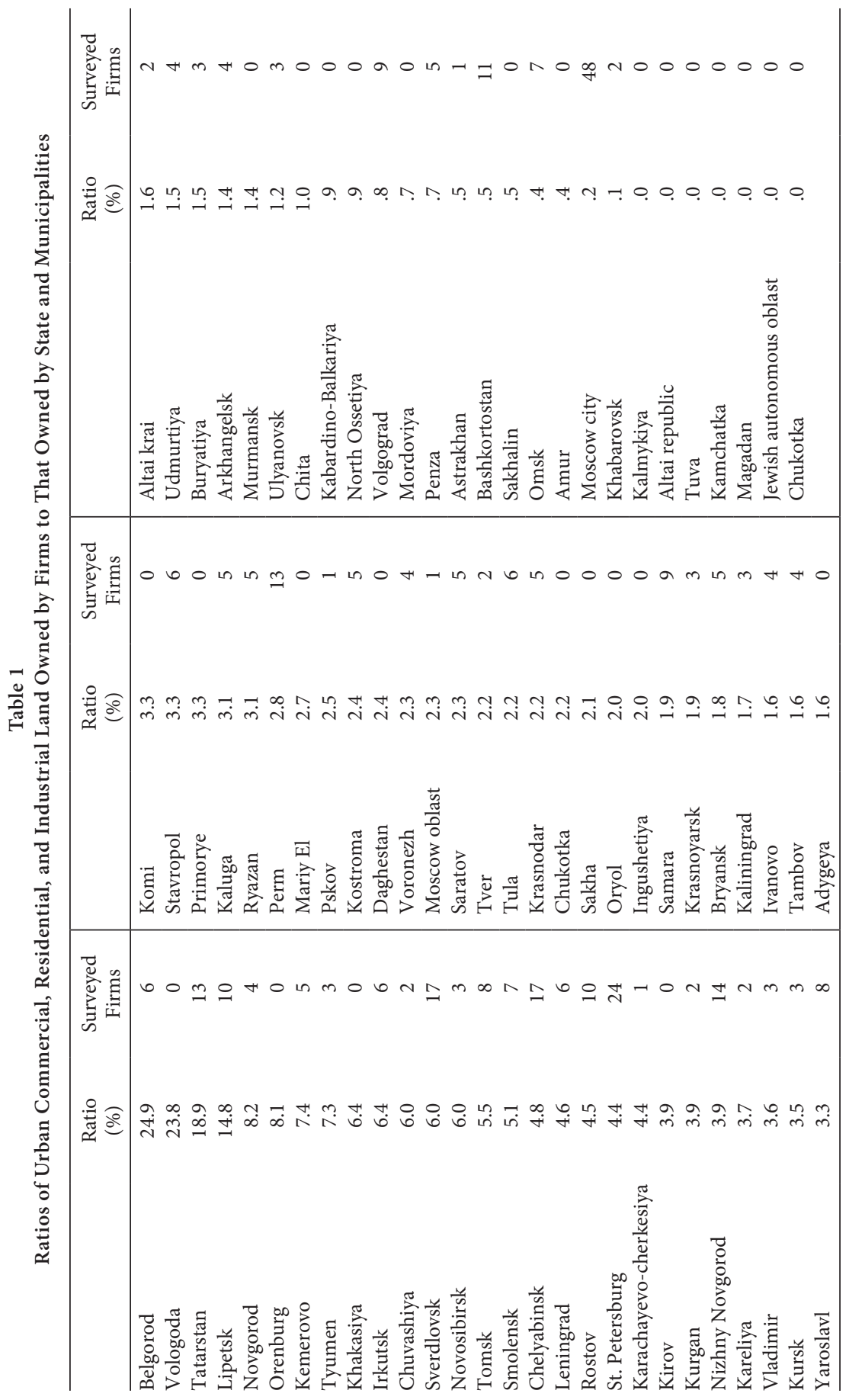

This content downloaded from 131.211.105.027 on July 18, 2016 03:19:38 AM All use subject to University of Chicago Press Terms and Conditions (http://www.journals.uchicago.edu/t-and-c). 
Table 2

Characteristics of Firms and Primary Production Plots by Land Tenure Status

\begin{tabular}{lccc}
\hline & Private & Lease & PPU \\
\hline Credit access and investment intensity: & & & \\
Difficulty accessing credit (1-5 scale) & $2.75^{+}$ & 2.83 & $3.46^{* *}$ \\
Investment intensity, 2009 (1-5 scale) & $2.76^{*}$ & 2.51 & $2.22^{*}$ \\
Firm characteristics: & & & \\
Full-time employees & $1,249.1$ & $1,368.5$ & $1,599.3$ \\
Years since privatization & 14.4 & 14.9 & 14.4 \\
Problems with inadequate working capital, overdue & & & \\
$\quad$ accounts receivable, corruption and (nonland) & & & \\
$\quad$ taxes (1-5 scale) & 3.21 & 3.26 & $3.50^{+}$ \\
Population of city in which firm is located (1-5 scale) & $3.0^{* *}$ & $3.8^{* *}$ & $3.0^{*}$ \\
Member of commercial group (\%) & 30.6 & 30.4 & 23.6 \\
Influence of State Property Fund (0-4 scale) & .35 & .35 & .54 \\
Influence of nonmanagement labor $(0-4$ scale) & 1.36 & 1.14 & 1.31 \\
Influence of foreigners (0-4 scale) & .46 & $.64^{*}$ & $.11^{* *}$ \\
Influence of other Russians (0-4 scale) & 1.47 & $1.01^{* *}$ & $1.82^{* *}$ \\
Profitability in 2007-8 (2-6 scale) & 5.38 & 5.24 & 5.16 \\
Primary production plot: & & & \\
Only plot attached when firm was privatized (\%) & 40.4 & 37.4 & $25.5^{+}$ \\
Attached when firm was privatized (\%) & 81.9 & 78.6 & 78.2 \\
Most environmentally hazardous (\%) & 4.7 & 6.1 & 3.6 \\
Located on edge of city (\%) & 43.9 & 51.1 & 54.5 \\
Nearby firms (1-3 scale) & 2.53 & $2.67^{+}$ & 2.49 \\
\hline
\end{tabular}

Note. Reported $p$-values are for $t$-tests on equality of means for those inside and outside the subgroup. $\mathrm{PPU}=$ permanent (perpetual) use.

${ }^{+} p<.10$.
${ }^{*} p<.05$.
${ }^{*} p<.01$.

their primary production plot under PPU rights-the weakest form of tenureare more apt to view credit access as a barrier than firms that own or lease their land. To shed light on the link between this qualitative variable measuring difficulty accessing credit and a potentially more tangible measure of the financial environment, for regions with more than five respondents we plotted the regional average against regional nominal loan growth between 2008 and 2009 (that is, the period roughly contemporaneous with the survey). The resulting relationship is negative, rather tight $\left(R^{2}=.32\right)$, and highly statistically significant $(p<.01)$. The relevant coefficient implies that when the regional average score indicating difficulty accessing credit rises by .7 of a unit (which, as shown in Table 2, is equivalent to the difference between the average score of firms with PPU rights to their plot and those that hold their land privately), regional loan growth falls by about 6 percent, a substantial effect relative to the sample average of 32 percent. ${ }^{12} \mathrm{Re}-$ sponding to a similarly scaled question about investment activity at the enterprise in 2009 (with 1 representing "no investment activity" and 5 "intense investment

\footnotetext{
${ }^{12}$ We cannot perform a similar matching of the qualitative question to a tangible performance indicator at the firm level because the firms' identities are not known to us.
} 
activity"), firms that own their plots reported greater intensity, and firms operating under PPU rights indicated less.

Firms in the sample had at the time of the survey, on average, over 1,000 employees and had been privatized nearly 15 years prior. ${ }^{13}$ Firms with PPU rights reported experiencing the most difficulty with a set of commonly reported problems-inadequate working capital, overdue accounts receivable, government corruption, and (nonproperty) taxes-and those that owned their plots reported the least; this latter difference, however, is not statistically significant. About one-quarter of respondents reported belonging to a commercial group, some of which may have supported internal capital markets and eased financial market frictions for their members (Perotti and Gelfer 2001). We observe that the ownership profile of firms varies somewhat across land tenure status; for instance, foreigners appear to have had less of an ownership presence in firms that hold land under PPU rights. Firms that own their plots are, on average, more profitable than others, but the difference, according to our rather coarse profitability scale of $2-6$, is not statistically significant. ${ }^{14}$

About 80 percent of the plots were attached to the enterprise at the time of its privatization. Roughly half of the primary production plots were located on the city's edge, as opposed to somewhere near the center or historic district, and a small number had been categorized as the most hazardous type of urban land from an environmental perspective.

Among the firms that own their primary production plots, the median year of land privatization was 2003. Two-thirds of these plots had been held in PPU prior to privatization, whereas the remainder had been leased. The transition from lease holding to private ownership became more common in more recent years. Sixty-seven firms paid less than the full cadastral value to purchase the plot (an average rate of 5.6 percent of the cadastral value, and a median of 2.5 percent), 41 paid the full cadastral value, and 20 reported paying a price tied to the annual land tax (an average factor of 9 times the tax amount, and a median of 5.5), four had "other" arrangements, and the rest did not answer that question. ${ }^{15}$

\section{Plot Tenure Status, Access to Credit, and Investment Intensity}

Table 2 documents strong unconditional correlations between the ease of access to credit and investment intensity on the one hand and plot tenure status on the other. Firms that own their plots reported higher investment activity and fewer problems with accessing credit. The reverse holds for firms with

\footnotetext{
${ }^{13}$ The median year of privatization was 1993. All had been privatized by the end of 2004, and 90 percent of firms surveyed had been privatized prior to 2001 .

${ }^{14}$ This variable was constructed by summing scaled responses to questions about profitability in 2007 and 2008 in which a response of 1, in a given year, was equivalent to making a loss, 2 to making neither a profit nor a loss, and 3 to making a profit.

${ }^{15}$ A substantial majority of firms that owned their plots reported paying a 1.5 percent land tax rate; 28 paid less, with the low being .4 percent. The average of all firms that reported a specific rate was 1.4 percent.
} 
PPU rights. In this section, we demonstrate that these correlations survive in a multiple-regression framework.

We consider a firm trying to finance an investment project with bank credit. A bank is likely to grant a loan (and, therefore, the project is likely to happen) if the firm is healthy and/or can provide collateral of sufficient value. We thus model a firm's access to credit and its investment intensity as a function of two broad sets of variables: those that capture a firm's current and expected future performance and those that characterize its available collateral, which in our context is its primary production plot. Among the characteristics of its primary production plot, we are most interested in its tenure status; other plot-related characteristics represent additional controls that potentially influence its value as a collateralizable asset.

We estimate the following ordered probit model:

$$
A_{i, j}=\alpha+\varphi T_{i}+\text { Controls }+\varepsilon_{i} .
$$

The dependent variable $A_{i, j}$ is the answer (expressed as the value of an ordered variable from 1 to 5 ) for the $i$ th firm to the $j$ th question ( $j=1$ or 2 ). For $j=1$, the question addresses the degree to which difficulties with accessing credit pose a severe problem for the firm; $A_{i, 1}$ ranges between 1, denoting no problem at all, and 5 , denoting a severe problem. For $j=2$, the question addresses the intensity of the firm's investment activity (in fixed capital, equipment, buildings, and land) in 2009; $A_{i, 2}$ ranges between 1 , denoting no activity at all, and 5, denoting intense activity.

The variable $T_{i}$ is a dummy representing the tenure status of the $i$ th firm's primary production plot. In most specifications, $T_{i}$ equals one if the plot is owned privately, and $T_{i}$ equals zero if it is either leased or held under PPU rights. We expect our coefficient of interest, $\varphi$, to be negative when firms address the question concerning difficulties with accessing credit, and we expect it to be positive when they address the question about investment intensity. That is, in line with the prediction of the de Soto effect, private tenure should be associated with fewer difficulties accessing credit and more intense investment activity. In some specifications, we include dummies that capture whether the plot is leased or held under PPU rights so as to compare these two different forms of land tenure to private ownership.

Tables 3 and 4 presents the results from the ordered probit models. Our baseline specification includes a standard control for the firm's size, its (log) number of full-time employees. To account for the possibility that the temporal sequencing of firms' privatization is related to their expected future performance (Gupta, Ham, and Svejnar 2008), the baseline specification also controls for the (log) number of years since the firm (not the plot) was privatized. Further, to control for non-land-related features of its operating environment that plausibly affect current and expected future performance, respondents to our survey were asked to assess on a scale from 1 to 5 the difficulties posed by four potential problems: taxes (not related to property), corruption, overdue accounts receivable, and in- 
adequate (own) working capital (with 1 representing "not at all" and 5 "extremely problematic"); the responses across each of these categories were summed and then divided by $4 .{ }^{16}$ Finally, our baseline specification includes a measure for the population of the city in which the firm is located, potentially capturing agglomeration and/or market-size effects. ${ }^{17}$

To this baseline specification we add descriptors of the primary production plot's history and geographic location, potentially important determinants of its value. These include dummies for being located on the edge of the city, for being attached to the firm at the time of the firm's privatization, for being the only plot attached to the enterprise at the time of the firm's privatization, and for being designated as the most dangerous in terms of environmental hazards. An additional plot-specific control captures on a 1-3 scale the number of enterprises in the plot's immediate vicinity: 1 represents none, 2 represents one or two, and 3 represents more than two.

We subsequently add variables that describe the firm's ownership structure, believing, in line with an extensive literature, that ownership is related to measures of firm performance. The inclusion of a dummy variable for membership in a commercial group (for example, a financial-industrial group or a holding company) is inspired by the finding of Perotti and Gelfer (2001) that such groups ease financial market frictions and facilitate the financing of investment for their members. Additional ownership variables measure on a $0-4$ scale the influence of foreigners, the State Property Fund, nonmanagement labor employed by the firm, and Russian individuals not employed by the firm. A score of 0 is recorded if the given individual, entity, or group has no representation among shareholders, 1 means that it has representation but little influence, and 4 denotes a great deal of influence. ${ }^{18}$ Brown, Earle, and Telgedy (2006) find that the effect of privatization on firm productivity is small or even negative in Russia, with the notable exception of privatization to foreign investors, which is found to affect firm productivity positively. In addition, there is a rich literature that illustrates that firms owned by their managers and/or workers perform considerably worse than firms with outside owners, be they institutional or individual. Djankov and Murrell (2002), for example, find for countries in the Commonwealth of Independent States that privatization to outsiders yields large productivity gains, whereas privatization to workers is detrimental to firm performance.

We further control for a firm's recent financial health by including an ordered variable, scaled from 2 to 6 , constructed by summing answers to questions on profitability in 2007 and 2008 in which a response of 1 in a given year indi-

\footnotetext{
${ }^{16}$ This variable can also be thought of as capturing otherwise-unobserved characteristics of the respondent that might lead to providing either overly positive or negative subjective assessments of the institutional environment. Institutional factors like corruption have been shown to be firm specific (Johnson, McMillan, and Woodruff 2002).

${ }^{17}$ The city size variable is scaled from 1 (cities under a quarter million residents) to 5 (cities over 3 million residents).

${ }^{18}$ Some of our control variables are ordered. In unreported results (available from the authors on request), we included them as series of dummies. The results were not affected in any material way.
} 


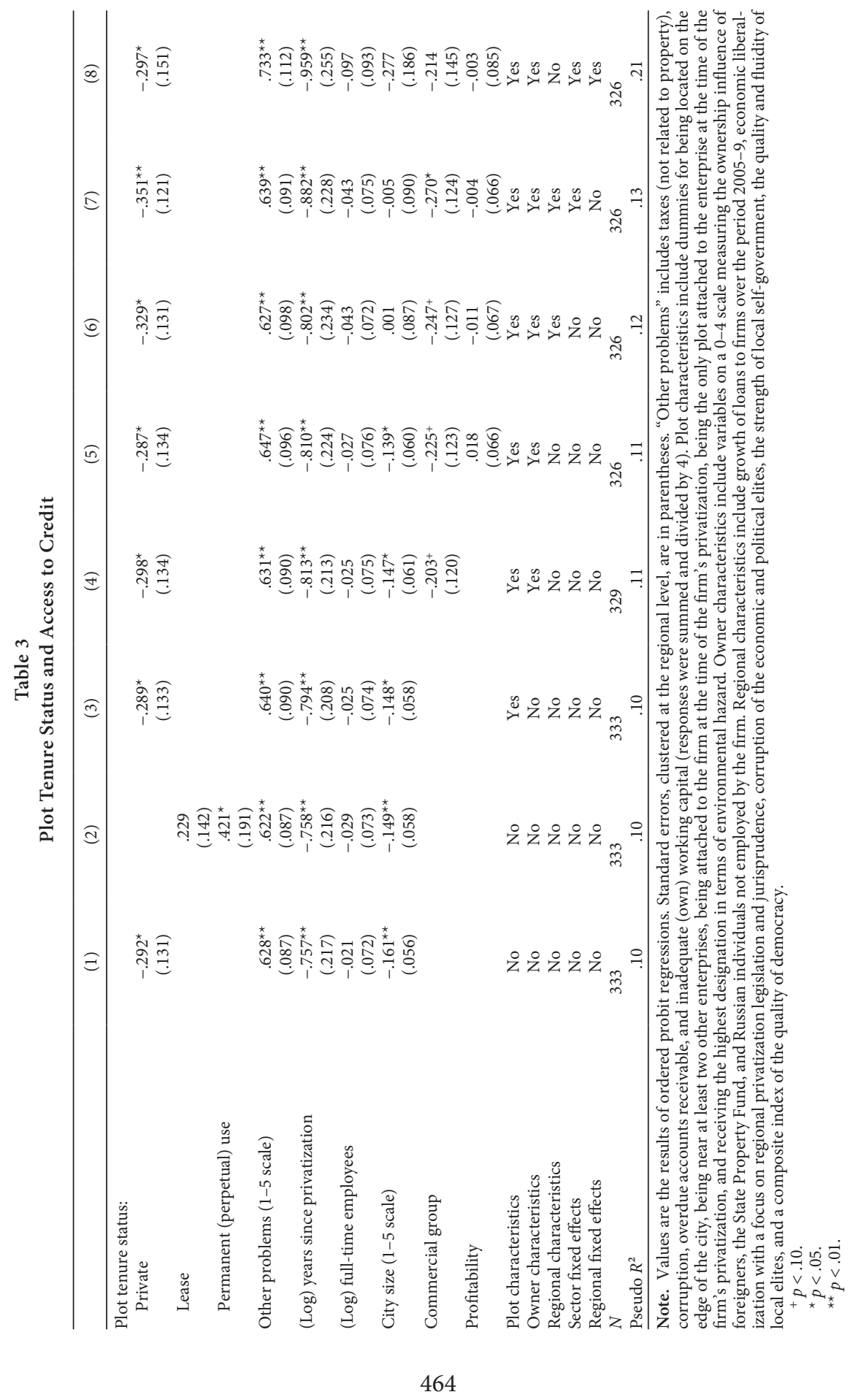

This content downloaded from 131.211.105.027 on July 18, 2016 03:19:38 AM All use subject to University of Chicago Press Terms and Conditions (http://www.journals.uchicago.edu/t-and-c). 


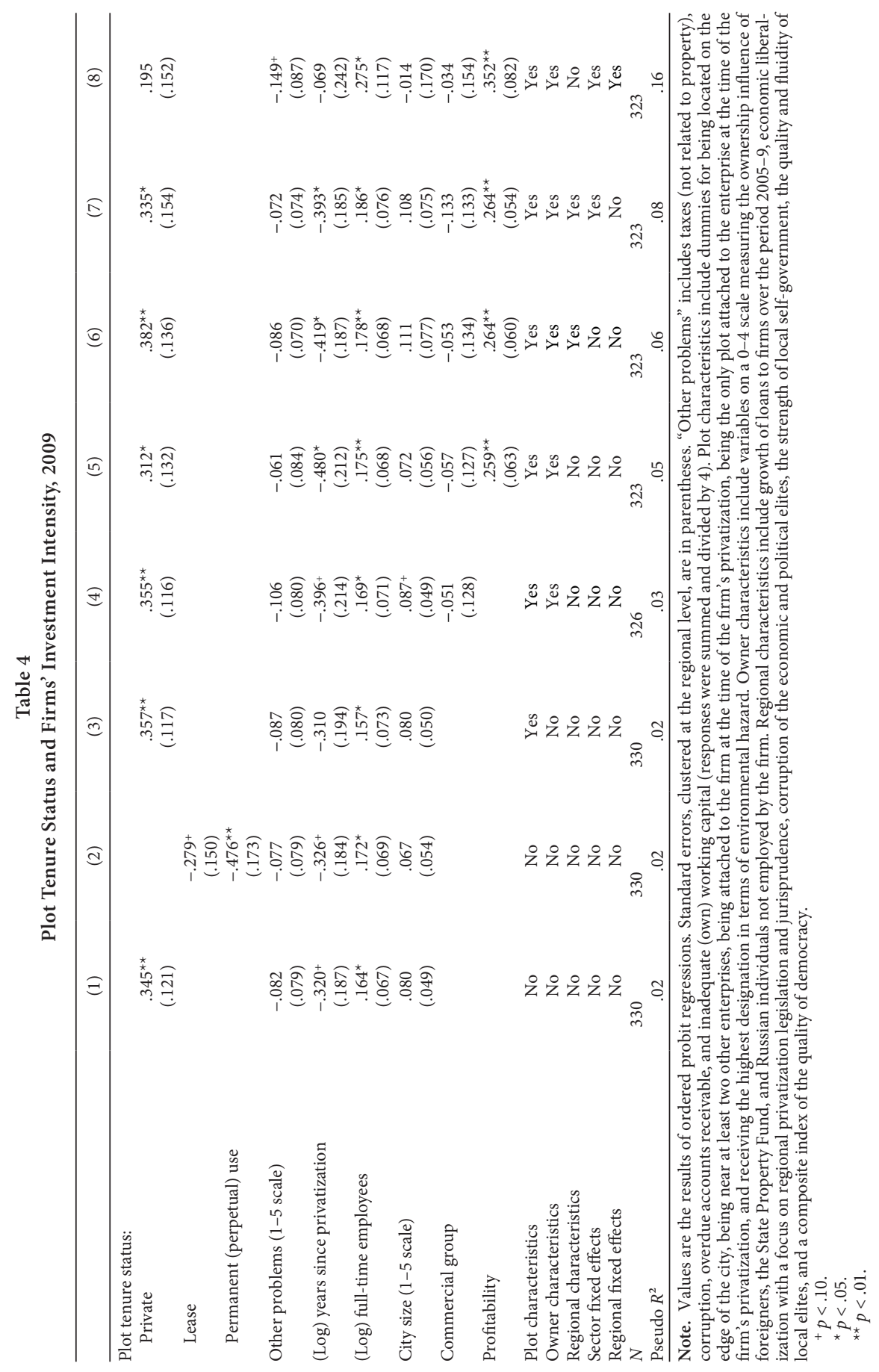

This content downloaded from 131.211.105.027 on July 18, 2016 03:19:38 AM All use subject to University of Chicago Press Terms and Conditions (http://www.journals.uchicago.edu/t-and-c). 
cates making a loss, 2 indicates making neither a profit nor a loss, and 3 indicates making a profit. Some models include controls for a set of regional characteristics plausibly connected to regional land policies and the behavior of the credit market. Growth of loans to firms over the period 2005-9 captures recent financial market development in the region. ${ }^{19}$ Five additional controls are drawn from a well-known expert survey characterizing political and economic differences across regions: economic liberalization, with a focus on regional privatization legislation and jurisprudence; corruption among the economic and political elites; the strength of local self-government; the quality and turnover among local elites; and a composite index of six other dimensions related to regional democracy. ${ }^{20}$ In the last two specifications, we add a set of sectoral fixed effects; the final specification replaces the regional characteristics with a set of regional fixed effects.

Tables 3 and 4 reveal a strong correlation between private land ownership and both dependent variables. Across specifications, firms that own their plots report less difficulty accessing credit (the negative coefficients for private plot status in Table 3) and higher investment intensity (the positive coefficients in Table 4). Conversely, firms that hold their land under the least secure tenure statusPPU-report more severe problems accessing credit than private landowners and comparatively little investment activity (column 2 in Tables 3 and 4). ${ }^{21}$ These results are in line with the de Soto-effect hypothesis that property rights facilitate access to credit and stimulate investment. ${ }^{22}$ We also observe some evidence that firms that belong to commercial groups and are located in larger cities report fewer problems with accessing credit and that larger and more profitable firms engage in investment more intensely.

\section{Exploiting Regional Variation in Land Policy}

Although the results in Tables 3 and 4 are consistent with the de Soto effect, they may be subject to omitted-variable bias. That is, we may have failed to in-

\footnotetext{
${ }^{19}$ The loan growth data are calculated from Bank of Russia $(2006,2010)$.

${ }^{20}$ For more information on the construction of the variables and the data, see Independent Institute for Social Policy, Social Atlas of the Russian Regions: Integrated Indexes [in Russian] (http:// atlas.socpol.ru/indexes/index_democr.shtml).

${ }^{21}$ The introduction of regional fixed effects reduces the coefficient on plot tenure status in the investment intensity equation by about half and makes it statistically insignificant (Table 4, column 8), which suggests that regional variation is important for identifying the effects of interest.

${ }^{22}$ To better assess magnitudes, we converted our ordered dependent variables into binary form and estimated probit models. The first new binary variable takes a value of one for firms reporting severe problems accessing credit (converted from values 4 and 5 on a scale from 1 to 5 ) and a value of zero for firms reporting few problems (original ordered values 1 and 2). Probit estimates indicate that private landownership reduces firms' probability of being in the group with severe problems by about 21 percentage points (while all other right-hand-side variables are held constant at their means). The second binary variable takes a value of one for firms reporting intense investment activity (converted from values 4 and 5) and a value of zero for firms reporting little activity (values 1 and 2). Probit estimates indicate that private landownership increases firms' probability of being in the group with intense activity by about 17 percentage points. Results are available from the authors on request.
} 
clude all relevant firm-level controls, including one or more correlated with our regressor of interest, the tenure status of the primary production plot. For example, imagine that our profitability measure is noisy and does not discriminate well between profitable and unprofitable firms. Further, suppose that profitable firms have both the funds to purchase their land and a healthy enough balance sheet to convince banks to extend credit. In that case, our regressions in Table 3 would still pick up a significant correlation between private landownership and ease of accessing credit even though there might not be a causal relationship between the two.

In this section, we address this possibility by using the regional measure of urban industrial land privatization (Table 1) as an index to instrument for the tenure status of a firm's primary production plot. ${ }^{23}$ As noted above, in spite of federal-level efforts to standardize land policy, regional officials have been able to influence the price, broadly understood, faced by firms wishing to assume ownership of the land they occupy. We interpret the data in Table 1 as capturing this variation in land policy across regions in a manner that is exogenous to individual firms. ${ }^{24}$ Where the value of the regional land index is high, we consider the policy environment conducive to plot privatization: firms incurred a lower cost in converting the tenure status of their production plots to private ownership.

Our interpretation of the land index as a suitable proxy for land policy is supported by anecdotal evidence. Moscow, for instance, which has a particularly low

${ }^{23}$ Altonji, Elder, and Taber (2005) propose an alternative way to address the potential omittedvariable bias. Suppose that we have one explanatory variable of interest and a large set of plausible controls. Further, assume that our choice of controls is perfect in the sense that the excluded variables (error term) have no correlation with our explanatory variable of interest and, thus, ordinary least squares (OLS) estimation is unbiased. We can then think of such an OLS estimate as providing an upper bound on the coefficient of interest; this upper bound corresponds to an estimate under ideal conditions of exogeneity. Now, suppose instead that our choice of controls is completely random. In that case, the correlation between the variable of interest and relevant unobserved variables is the same as the correlation between the variable of interest and observed control variables. Altonji, Elder, and Taber (2005) show how to use this assumption (in place of the no-correlation assumption) to obtain a lower-bound estimate on the coefficient of interest. We perform the above-mentioned sensitivity analysis using Stata's user-written program rcr.ado (Krauth 2011), which has two limitations: it estimates only OLS and can handle at most 25 controls. For this exercise, we thus perform OLS regressions of access to credit and investment intensity on all explanatory variables with the exception of regional fixed effects and ownership influence (the latter were not jointly statistically significant at the 5 percent level). Excluding these two groups of variables allows us to include fewer than 25 controls. Our results for the access-to-credit regressions turn out to be robust. Moving from an assumption of no correlation to one of equal correlation increases the magnitude of the coefficient on private landownership (from -.36 to -.57). A conservative confidence interval (that is, with the lower bound for the lower estimate and higher bound for the higher estimate) does not contain 0 . Our results for investment-intensity regressions are partially robust. Moving from an assumption of no correlation to one of equal correlation leaves the point estimate of the coefficient on private landownership virtually intact (at .37), however, with a much larger standard error. As a result, a conservative confidence interval contains 0 . Results are available from the authors on request.

${ }^{24}$ A claim of exogeneity implies that the regional share of private land is not influenced by any of the surveyed firms that own their primary production plot. Eleven of the 359 firms in the database, however, do own a plot whose size accounts for at least 10 percent of the private land in the region (the numerator in the land index). To ensure that our instrumental variables (IV) results are not driven by these firms, we reestimated the models in Table 6 without them. Our results of interest did not change appreciably. 
value in the index, formally banned the sale of land in the 1990s, and despite the passage of the 2001 land code, policy in the capital city has remained hostile to plot privatization (Kisunko and Coolidge 2007).

We would, however, like to provide more systematic evidence that the index indeed captures land policy variation across regions. We thus examine the responses to a survey question asking firms that had assumed ownership of their land to assess on a 1-5 scale the severity of eight potential obstacles in privatizing their primary production plot. Just over half of the 169 firms that answered this question chose 1 in response to "opposition of local officials," indicating little to no opposition. Just under 10 percent of firms, however, chose 5 , reflecting that local officials had put up severe roadblocks to the process's completion. The average response was 2.1.

If our land index captures the policy variation that we claim, we would expect it to explain the variation in the response to this question. That is, we would expect a negative correlation between its value and the assessment of individual firmsin particular, those that had experienced the process of plot privatization from beginning to end-as to the degree of opposition presented by government officials. We present tests for this relationship in Table 5. Controlling for the same firm and plot characteristics we included in the models in Tables 3 and 4 , as well as for the seven other perceived barriers to plot privatization, we see that firms owning their primary production plots (column 1) are less likely to characterize government opposition as a significant barrier to plot privatization if they are located in regions in which the index of land privatization is high. ${ }^{25}$ This effect is statistically significant at the 5 percent level.

Our identification strategy relies on an assumption that firms make decisions about the tenure status of their plots in response to a regional policy environment that affects the price of privatizing their plots. Of course, some firms took ownership of their plots early in the postcommunist period, responding to reforms in the 1990s; the majority, however, privatized their land more recently, after the passage of the land code. By using an instrument that measures the regional stock of urban land that had been privatized by 2008 , we assume that the pattern of regional policy variation in the year prior to the survey (that is, 2008) is similar to the pattern that prevailed earlier. That is, in general, regions that were amenable (hostile) to plot privatization later in the reform period were also more amenable (hostile) earlier on. We put this assumption to the test in columns 2 and 3 of Table 5. In column 2, we estimate the same model for firms that had privatized their plots before 2005; this leaves us with about two-thirds of the firms that reported owning their primary production plots at the time of the survey in 2009. In column 3, we include only firms that had privatized their plots after 2000. Again, we are left with about two-thirds of all firms that reported owning their plots. In both samples, we observe that firms' perception of government opposition is

\footnotetext{
${ }^{25}$ We control for the average of a firm's responses to the other questions about barriers so as to diminish the likelihood that results are driven by unobserved variation in firms' willingness to respond with systematically higher or lower responses across all barriers.
} 
Table 5

Opposition of Local Officials as a Barrier to Privatizing the Plot (1-5 Scale)

\begin{tabular}{lccc}
\hline & & \multicolumn{2}{c}{ Timing of Plot Privatization } \\
\cline { 3 - 4 } & All & Before 2005 & $\begin{array}{c}\text { After } 2000 \\
(3)\end{array}$ \\
\hline (Log) ratio of land owned by firms to & $(1)$ & & $(2)$ \\
that owned by government (\%) & $-.322^{*}$ & $-.544^{* *}$ & $-.382^{*}$ \\
$N$ & $(.150)$ & $(.174)$ & $(.182)$ \\
Pseudo $R^{2}$ & 168 & 105 & .29 \\
\hline
\end{tabular}

Note. Values are the results of ordered probit regressions. Robust standard errors, adjusted for clustering at the regional level, are in parentheses. All models include controls for other barriers, sector, plot characteristics, and owner. "Other barriers" include problems defining and agreeing on plot boundaries, the inadequacy of resources (difficulty accessing credit), the high cost of completing documents to purchase land, the incomplete process of assigning land to the appropriate government level, and the absence of documents conferring rights to land.

${ }^{*} p<.05$.

${ }_{* *}^{*} p<.01$.

inversely related to the land index. That is, whether we consider the two-thirds of firms that privatized their plots early or the two-thirds of firms that privatized their plots late, our land index explains perceptions of government resistance, a finding consistent with the index capturing a consistent pattern of regional policy variation across time.

Having provided evidence that the land index can serve as a reasonable proxy for regional land policy, we now turn to its suitability as an instrument to identify the causal effect of plot tenure status on access to credit and investment intensity. To qualify as suitable, the index must predict plot tenure status when other factors are held constant. That is, a firm in a region in which the index indicates that policy is friendlier to private land tenure should be more likely than a similar firm in a region with a less amenable policy environment to report owning its primary production plot. This condition is easily tested. And, indeed, our first-stage regressions in Table 6 document strong predictive power.

In addition, a suitable instrument must satisfy the exclusion restriction. In other words, it should be uncorrelated with the error term (with all the omitted factors affecting access to credit and investment intensity) in the second-stage regressions. Although we cannot test this condition, we believe that the land index is likely to satisfy it. On the one hand, it is difficult to conceive of a channel (other than landownership) through which land policy might affect a firm's access to credit and investment intensity. On the other hand, while it is possible that regional variation in land policy is correlated with regional variation in other factors that might influence bank behavior and/or the investment climate (for example, other dimensions of the regional institutional environment), we do include the same diverse set of six regional controls (discussed in Section 4) in both the first and second stages of all IV specifications: growth of loans to firms over the period 2005 to 2009 , economic liberalization with a focus on regional privatization legislation and jurisprudence, corruption of the economic and politi- 
cal elites, the strength of local self-government, the quality and turnover of local elites, and a composite index capturing the quality of democracy.

Even if our instrument satisfies these two conditions, it might fall short of identifying the population-average effect of private landownership on our two outcome measures because of essential heterogeneity (Heckman, Urzua, and Vytlacil 2006). In the process of producing controlled variation in the suspected endogenous regressor (plot tenure status), the instrument necessarily restricts identification to the subpopulation of firms for whom plot tenure status would change because of the instrument (Imbens and Wooldridge 2007). That is, we identify a local average treatment effect (Angrist, Imbens, and Rubin 1996) of private landownership on both access to credit and investment intensity for those firms that would not assume ownership of their plots if located in a region with a lower value for the land index but would assume ownership if located in a region with a higher value for the index. One should be cautious when extrapolating this local average treatment effect to other subpopulations of firms, especially if firms that expect to benefit more from plot ownership (in the sense, for example, of having better access to credit) are also more likely to respond to a policy friendly to land privatization by assuming ownership of their plot. Indeed, if firms sort on the gain in this manner, then the local average treatment effect may identify the causal effect of private landownership for a subpopulation of firms that would benefit from it (Heckman, Urzua, and Vytlacil 2006). In this case, the estimated effect would be upwardly biased compared to the average treatment effect for the population as a whole.

We present the results of this IV approach in Table $6 .{ }^{26}$ The first-stage IV regression results show that the regional land policy index strongly predicts private plot status across specifications. Observing that surveyed firms are more likely to have taken ownership of their primary production plot in regions where the index of urban industrial land privatization is high, even after controlling for a number of firm- and plot-specific characteristics, gives us confidence that the index is capturing the land policy variation that we have argued it does and is therefore an appropriate instrument. The second-stage results show a statistically significant negative relationship between the predicted value of private plot status and the firm's reported difficulty in accessing credit, while finding a statistically significant positive relationship with the firm's investment intensity. This is true for all specifications. The IV estimation results reinforce the ordered probit re-

\footnotetext{
${ }^{26}$ Given that our dependent variables (access to credit and investment intensity) are ordinal, while the endogenous regressor, plot tenure status, is binary, we cannot rely on the standard twostage least squares (2SLS) estimation procedure, which is known to work only approximately in these circumstances (Miranda and Rabe-Hesketh 2006). Instead, we estimate the model in one step by maximum likelihood methods using a Stata routine, ssm, which, in turn, is a wrapper for another routine, gllamm, designed to estimate endogenous switching models. The setup in these models is comparable to 2SLS: the switching equation (probit) is similar to the first-stage regression and models plot tenure status as a function of the land index (the instrument) and all other explanatory variables; the outcome equation (ordered probit) is similar to the second-stage regression and models credit access or investment intensity as a function of (predicted) plot tenure status and all other explanatory variables (for details, see Miranda and Rabe-Hesketh 2006).
} 


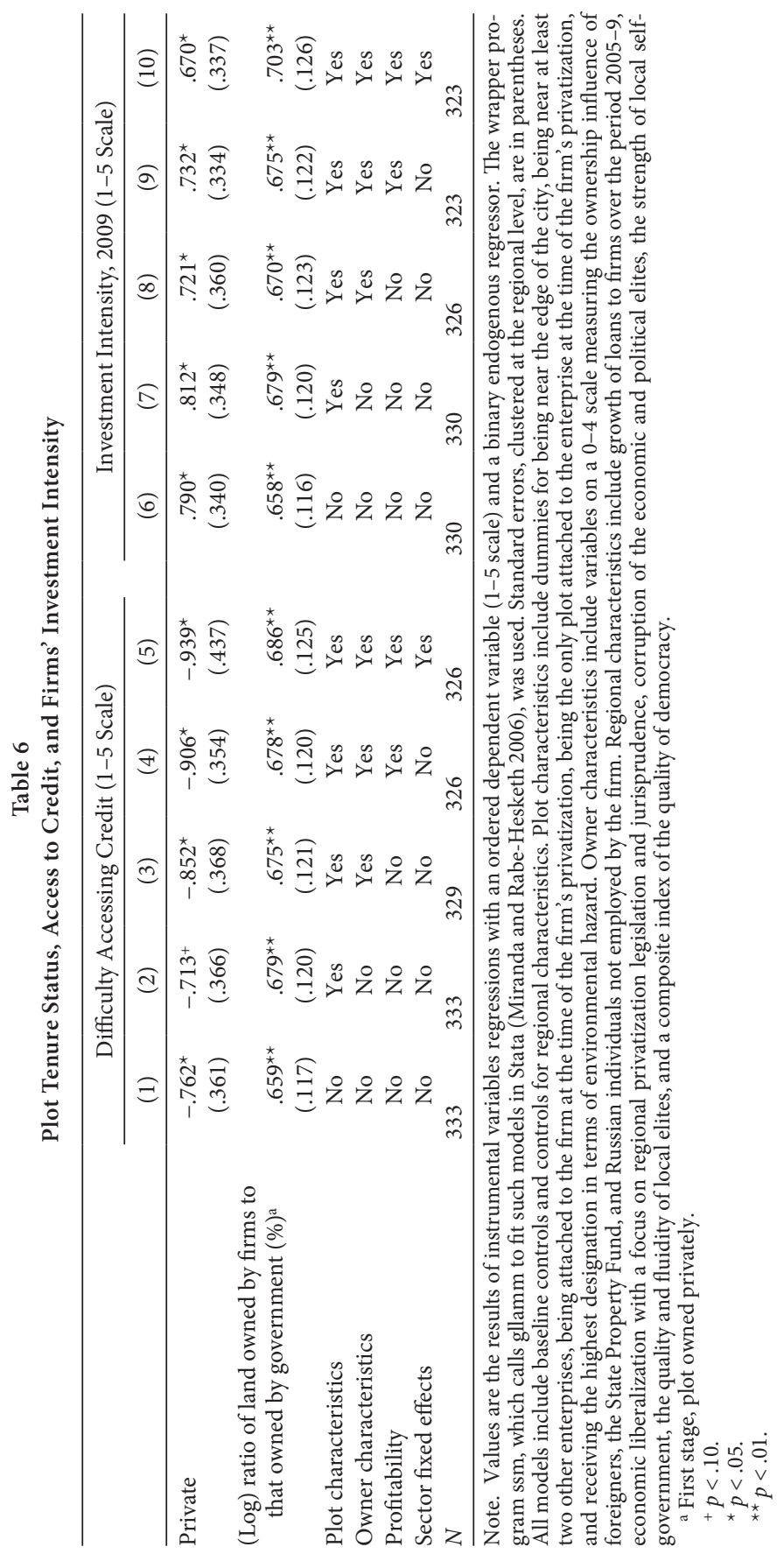

This content downloaded from 131.211.105.027 on July 18, 2016 03:19:38 AM All use subject to University of Chicago Press Terms and Conditions (http://www.journals.uchicago.edu/t-and-c). 
gression results in Tables 3 and 4. Our IV regressions, in other words, provide further support for a de Soto effect in industry. We should note, however, that our IV effects are consistently larger than the probit effects found in Tables 3 and 4 , a difference consistent with the phenomenon of sorting on the gain and thus consistent with the possibility that the strength of the de Soto effect does not generalize to all firms.

\section{Understanding Regional Variation in Land Policy}

By introducing a source of regional variation that plausibly explains an individual firm's plot tenure status, our IV strategy allows us to address identification problems relating to reverse causality and firm-level omitted variables. However, we recognize that land policy was unlikely to have been randomly assigned in the manner of a true natural experiment. And although we control for other, nonland-related regional factors that may explain firms' access to credit and investment activity, we recognize that we may not observe one or more additional regional variables that explain land policy and the financial environment. That is, it is possible that regional land policy is itself endogenous. We thus looked, ultimately without success, for deeper, more historical drivers of regional land policy that could serve as plausible alternative instruments. This search, of course, was complicated by the requirement that any alternative instrument's effect on our dependent variables occurs exclusively through the land tenure channel.

Despite failing to identify convincing alternatives that satisfy the exclusion restriction, we see value in exploring the historical determinants of regional land policy. For although the postcommunist transition has produced an abundance of articles addressing the effect of asset privatization, it has engendered few that identify factors governing public officials' decisions to relinquish ownership over some assets but not over others. ${ }^{27}$ To understand the forces that might be at work here, we highlight that status of land as a rent-generating asset. Where rents are greater, one might surmise, potentially corrupt officials should be more reluctant to cede ownership control. That is, where land values are higher, the supply of policies conducive to plot privatization should, all else equal, be lower. And, controlling for this determinant of policy supply, we would expect that regions with stronger industrial interests would have a policy environment more amenable to private ownership in equilibrium.

To proxy for these underlying forces, we turn to several variables as measured in 1995, soon after market and political liberalization but before land plots had begun to be systematically privatized in any of Russia's regions. A region's ur-

\footnotetext{
${ }^{27}$ Some researchers focus on officials' concern with the unemployment and political opposition that might arise from simultaneous privatization of all state enterprises without focusing on why some might be privatized before others (Glaeser and Sheinkman 1996; Dewatripont and Roland 1995). Gupta, Ham, and Svejnar (2008) use firm-level data from the Czech Republic to show that those privatized first been more profitable and operated in downstream industries subject to greater demand uncertainty - which suggests, they argue, that officials had an efficiency objective in choosing which to privatize first.
} 
Table 7

Regional Determinants of Urban Land Privatization

\begin{tabular}{lcccc}
\hline & 1995 & 2007 & 1995 & 2007 \\
& $(1)$ & $(2)$ & $(3)$ & $(4)$ \\
\hline Log) industrial production per capita & $.76^{* *}$ & $.43^{* *}$ & $.70^{* *}$ & .00 \\
Share of loss-making enterprises & $(.143)$ & $(.125)$ & $(.180)$ & $(.150)$ \\
& $-.02^{* *}$ & -1.89 & $-.02^{\star}$ & -.76 \\
(Log) income per capita & $(.007)$ & $(1.575)$ & $(.009)$ & $(1.431)$ \\
Share of population that is urban & $-.52^{*}$ & -.27 & -.46 & -.20 \\
& $(.257)$ & $(.283)$ & $(.292)$ & $(.253)$ \\
Fitted values for the other year & $-.02^{*}$ & -.01 & $-.02^{*}$ & .00 \\
& $(.008)$ & $(.009)$ & $(.008)$ & $(.009)$ \\
$R^{2}$ & & & .14 & $.96^{* *}$ \\
\end{tabular}

Note. Values are the results of ordinary least squares regressions. Standard errors are in parentheses. The constant is not reported. The dependent variable is the land index as measured on January $1,2008 . N=76$.

${ }^{*} p<.05$.

${ }^{* *} p<.01$.

banization rate and its per capita income capture its urban land values, the driver of policy supply. Where they are greater, we hypothesize, the land policy index will be lower. Officials in such regions, that is, should be more resistant to federal privatization initiatives so as to preserve the more lucrative, rent-generating opportunities that accompany control over higher-valued land. We capture the demand for urban industrial land privatization with measures of the regional percentage of loss-making enterprises and industrial production per capita. In regions where the latter is higher, the demand for institutions that facilitate private ownership of urban industrial land should be greater. However, where the liberalization of prices in 1992 uncovered a local economy ill prepared for markets, as measured by the prevalence of loss-making firms in 1995, the immediate demand for land privatization should be less.

We present a test of these hypotheses in column 1 of Table 7. As hypothesized, regional income per capita and urbanization, as measured in 1995, are negatively related to the land policy index. In addition, the two demand-side proxies explain policy variation in the expected manner. Higher levels of industrial production per capita and a smaller percentage of loss-making firms are both associated with more urban land privatization. Each of these relationships is statistically significant at either the 1 percent or the 5 percent level. Early post-Soviet variation in regional economies, in sum, explains a good deal of the variation in regional land policy over the subsequent decade-plus period.

Consistent with this story that the index reflects forces that have influenced land policy over an extended period of time, we would expect that more recent values of the same variables would have less predictive power. Column 2 confirms that this is the case. Values from 2007 explain much less of the variation in the land policy index than the values of those same variables from 1995. Furthering this line of reasoning, we conduct Davidson-MacKinnon tests. We observe 
Table 8

Plot Tenure Status and Access to Credit, by Year after Privatization

\begin{tabular}{lcccccc}
\hline & All Firms & 2009 & 2008 & 2007 & 2006 & 2005 \\
\hline Private & $-.297^{*}$ & $-.348^{*}$ & $-.313^{+}$ & $-.333^{+}$ & $-.403^{*}$ & $-.408^{+}$ \\
& $(.151)$ & $(.151)$ & $(.162)$ & $(.170)$ & $(.193)$ & $(.223)$ \\
$N$ & 326 & 314 & 296 & 284 & 275 & 269 \\
Pseudo $R^{2}$ & .21 & .10 & .10 & .11 & .11 & .12 \\
\hline
\end{tabular}

Note. Values are the results of ordered probit regressions and include controls for plot and owner characteristics and sector and regional fixed effects. Standard errors, clustered at the regional level, are in parentheses.

$+p<.10$.

${ }^{*} p<.05$.

in column 3 that inserting as an additional control the fitted value based on 2007 variables from column 2 adds effectively no predictive power to the 1995 variables. Conversely, as can be seen in column 4, the fitted value from the model based on 1995 values overwhelms the predictive power of the 2007 measures. ${ }^{28}$

\section{Robustness and Additional Survey-Based Evidence}

To supplement the IV specifications, we return to potential sources of reverse causality in the correlations highlighted in Tables 3 and 4. First, with respect to the regressions in Table 3, it is worth noting that the dependent variable is not time specific. Firms characterizing credit conditions as favorable at the time of the survey may have been influenced by a favorable financial environment in the preceding years. It is thus not inconceivable that favorable credit conditions in, say, 2007 or 2008 facilitated subsequent land purchases. Causality, that is, might run from credit access to land acquisition rather than the other way around. We address this potential problem through the IV strategy presented in Table 6. But we can address it in an another way by repeating the regressions of Table 3 while excluding from the sample firms that privatized their plots in the most recent years. In Table 8 we do precisely this. The first column includes all sample firms and simply repeats the regional-fixed-effects specification in column 8 of Table 3 . Subsequent columns represent the specification but progressively eliminate firms that privatized their plots until finally eliminating those that privatized their plots after 2005. The number of firms gradually diminishes, but the relationship between private plot status and access to credit remains intact. If anything, the coefficient on plot tenure status becomes even greater, which suggests that the possible reverse-causation explanation outlined above is not a concern.

A slightly different reverse-causality concern arises in the investment intensity regressions. Recall that the investment question is time specific; firms, that is, were asked about activity in 2009 . We thus cannot rule out the possibility

\footnotetext{
${ }^{28}$ When we reestimate the models from Table 6 using the 1995 structural measures as alternative instruments, the relationships between land tenure, on the one hand, and credit access and investment intensity, on the other, remain much the same.
} 
that a portion of 2009 investment includes payment for the primary production plot. To eliminate this as a possible explanation for the relationships highlighted above, we redefine our independent variable of interest to be one only if the firm owned its plot prior to 2009. We then repeat the ordered probit regressions of Table 4 and the IV regressions of Table 5. The results, reported in Table 9, confirm our previous findings that private landownership drives investment activity and not the other way around.

We also wish to draw attention to questions from the survey that solicited respondents' opinions about the relationship between land and credit. Economic research tends to discount evidence gleaned from asking respondents for their personal thoughts on the relationship between two variables; it tends to be better form to demonstrate the relationship between those variables with statistical and econometric tools. But having done this already, we look to specially crafted survey questions for additional confirmation of a de Soto effect. One question, for instance, addressed prevailing norms requiring the pledge of land as collateral to secure external financing: "According to your experience, and those of your business colleagues ... how frequently do banks demand, as collateral to secure a long-term loan, the plot of land on which the firm's production takes place?" Of all respondents, 38.3 percent characterized the practice as extremely common (by giving a response of 5 on a 1-5 scale), and over half responded with a 4 or a 5 . Although this evidence indicates that pledging land facilitates access to credit, the wording of the question does not directly address the importance of land tenure. Fortunately, firms that had taken ownership of their plot were specifically asked about their motivation, and 42.4 percent of them cited access to external lending as an extremely important factor (5 on a 1-5 scale). Perhaps not surprisingly, this motive was even more popular among managers at firms that privatized their plots after the passage of the land code, when financial markets were better developed.

Finally, although we do not want to read too much into it, we highlight a noteworthy correlation between our survey evidence and regional macroeconomic outcomes. Extrapolating from the enterprise-level finding that private land tenure reduces financial market frictions and promotes investment, we might expect that regions that privatized land earlier would subsequently demonstrate higher levels of growth. Indeed, this is what we observe. For each region in our survey, we compute the average year that surveyed firms reported having privatized their primary production plots (for those that reported having taken ownership of them). Regressing the percentage change in regional gross product across two periods (2002-7 and 2002-9) on this measure, we find statistically significant negative relationships (at the 5 percent level). That is, in those regions in which firms took ownership of their plots in an earlier year on average, the growth rates in the aftermath of the passage of the land code were higher. 


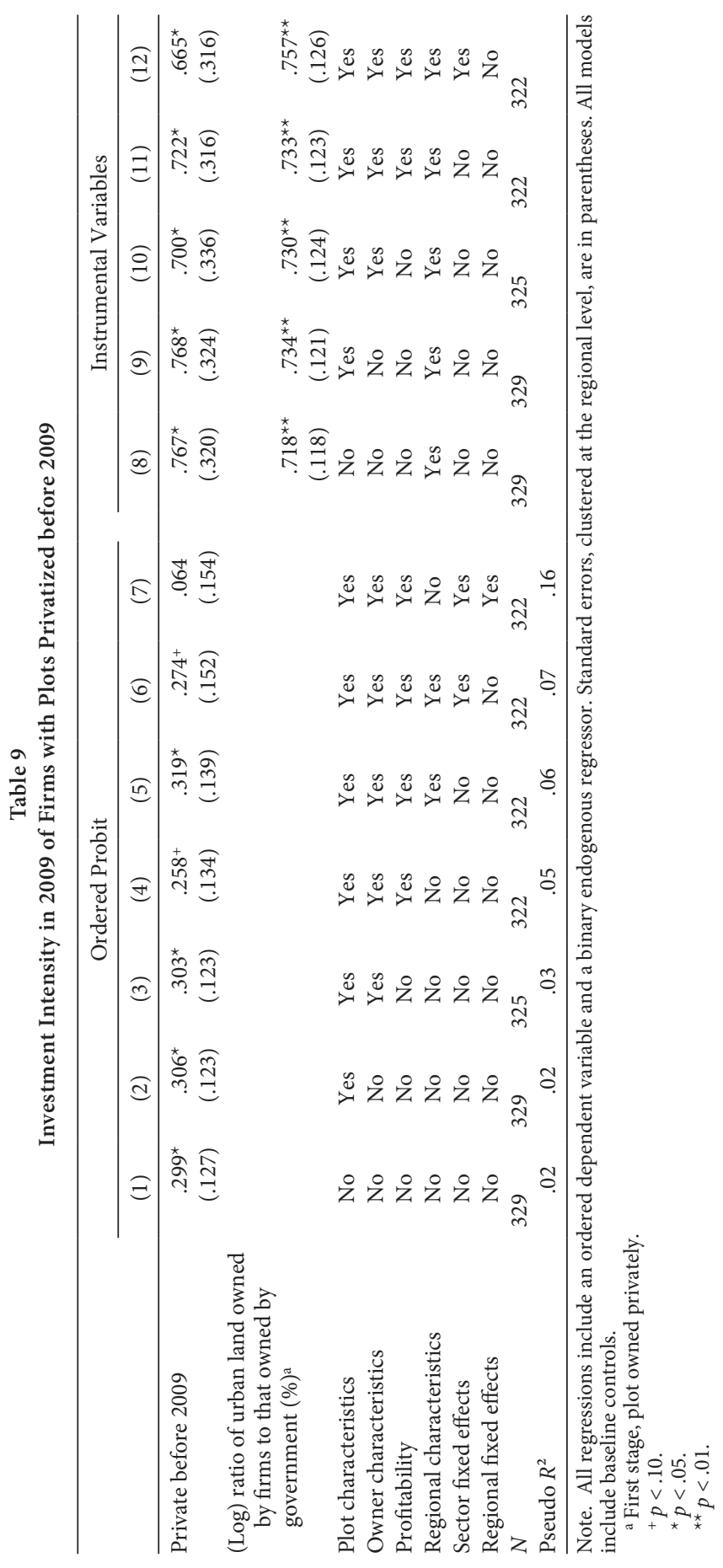

This content downloaded from 131.211.105.027 on July 18, 2016 03:19:38 AM All use subject to University of Chicago Press Terms and Conditions (http://www.journals.uchicago.edu/t-and-c). 


\section{Conclusion}

We have investigated the financial impact of private land tenure in a setting in which non-land-related credit market frictions are apt to be relatively mild. In the eyes of commercial lenders, large and well-established urban enterprises are not the equals of either poor farmers or the denizens of sprawling slums. So from the standpoint of identifying a de Soto effect, they would seem to be more appropriate units of analysis. We do indeed observe that plot ownership is associated with greater success in accessing external financing and more intense investment activity in our sample of large, well-established industrial firms, which lends support for the presence of a de Soto effect among this group.

As have the authors of prior studies, we grapple with endogeneity concerns. They are twofold. First, instead of capturing a de Soto effect, it is not inconceivable that the conditional correlations arise from omitted firm-level variables and/or reverse causation. Our IV strategy, which exploits substantial land-related policy variation across Russia's federal subjects, minimizes these potentialities. However, this strategy raises its own concerns. For one, the local average treatment effect that we estimate, and by consequence the strength of the de Soto effect that we identify, may not generalize to all firms. In addition, regional land policy may itself be endogenous. Though this is hardly a trivial matter, we again draw attention to two pieces of evidence suggesting that the identified relationships are not a function of unobserved regional variation: first, the correlation between private land tenure and financial outcomes survives the inclusion of regional fixed effects, and, second, the IV specifications include a rich set of regional controls. Finally, by way of concluding, we once again highlight the responses of the firms' managers to direct questions. When pressed to identify a motivation for taking ownership of their land, managers at large industrial firms pointed to its value as a pledgeable asset. To the actors on the ground, in other words, the de Soto effect is a reality.

\section{References}

Alston, Lee, Gary Libecap, and Robert Schneider. 1996. The Determinants and Impact of Property Rights: Land Titles on the Brazilian Frontier. Journal of Law, Economics, and Organization 12:25-61.

Altonji, Joseph, Todd Elder, and Christopher Taber. 2005. Selection on Observed and Unobserved Variables: Assessing the Effectiveness of Catholic Schools. Journal of Political Economy 113:151-84.

Angrist, Joshua, Guido Imbens, and Donald Rubin. 1996. Identification of Causal Effects Using Instrumental Variables. Journal of the American Statistical Association 91:444-72. Aslund, Anders. 2007. Russia's Capitalist Revolution: Why Market Reform Succeeded and Democracy Failed. Washington, DC: Peterson Institute for International Economics.

Bank of Russia. 2006. Bulletin of Banking Statistics, Regional Supplement. No. 1. http:// www.cbr.ru/Eng/publ/BBS/Bbsq0601e.pdf.

. 2010. Bulletin of Banking Statistics, Regional Supplement. No. 1. http://www.cbr.ru/ Eng/publ/BBS/Bbsq1001e.pdf. 
Bertaud, Alain, and Bertrand Renaud. 1997. Socialist Cities without Land Markets. Journal of Urban Economics 41:137-51.

Besley, Timothy. 1995. Property Rights and Investment Incentives: Theory and Evidence from Ghana. Lournal of Political Economy 103:903-37.

Besley, Timothy, Konrad Burchardi, and Matireesh Ghatak. 2012. Incentives and the De Soto Effect. Quarterly Journal of Economics 127:237-82.

Boycko, Maxim, Andrei Shleifer, and Robert Vishny. 1995. Privatizing Russia. Cambridge, MA: MIT Press.

Braselle, Anne-Sophie, Frederic Gaspart, and Jean-Philippe Platteau. 2002. Land Tenure Security and Investment Incentives: Puzzling Evidence from Burkina Faso. Journal of Development Economics 67:373-418.

Brown, David, John Earle, and Almos Telegdy. 2006. The Productivity Effects of Privatization: Longitudinal Estimates from Hungary, Romania, Russia, and Ukraine. Journal of Political Economy 114:61-99.

Dewatripont, Mathias, and Gerard Roland. 1995. The Design of Reform Packages under Uncertainty. American Economic Review 85:1207-23.

Djankov, Simeon, and Peter Murrell. 2002. Enterprise Restructuring in Transition: A Quantitative Survey. Journal of Economic Literature 40:739-92.

Do, Quy Toan, and Lakshmi Iyer. 2008. Land Titling and Rural Transition in Vietnam. Economic Development and Cultural Change 56:531-79.

Estrin, Saul, Jan Hanousek, Evzen Kocenda, and Jan Svejnar. 2009. The Effects of Privatization and Ownership in Transition Economies. Journal of Economic Literature 47:699-728.

Field, Erica. 2005. Property Rights and Investment in Urban Slums. Journal of the European Economic Association 3:279-90.

Field, Erica, and Maxim Torero. 2008. Do Property Titles Increase Credit Access among the Urban Poor? Evidence from a Nationwide Titling Program. Unpublished manuscript. Duke University, Department of Economics, Durham, NC.

Galiani, Sebastian, and Ernesto Schargrodsky. 2010. Property Rights for the Poor: Effects of Land Titling. Journal of Public Economics 94:700-29.

Glaeser, Edward, and José Scheinkman. 1996. The Transition to Free Markets: Where to Begin Privatization. Journal of Comparative Economics 22:23-42.

Gosudarstvennyi doklad o sostoianiiiispol'zovaniizemel' v rossiiskoifederatsii v 2000 godu. 2001. Federal Service for the Land Cadastre, Moscow.

Gosudarstvennyi doklad o sostoianiiiispol'zovaniizemel' v rossiiskoifederatsii v 2001 godu. 2002. Federal Service for the Land Cadastre, Moscow.

Gosudarstvennyi doklad o sostoianiiiispol'zovaniizemel' v rossiiskoifederatsii v 2002 godu. 2003. Federal Service for the Land Cadastre, Moscow.

Gosudarstvennyi doklad o sostoianiiiispol'zovaniizemel' $v$ rossiiskoifederatsii $v 2003$ godu. 2004. Federal Agency for the Real Estate Cadastre, Moscow.

Gosudarstvennyi doklad o sostoianiiiispol'zovaniizemel' v rossiiskoifederatsii v 2004 godu. 2005. Federal Agency for the Real Estate Cadastre, Moscow.

Gosudarstvennyi doklad o sostoianiiiispol'zovaniizemel' v rossiiskoifederatsii v 2005 godu. 2006. Ministry of Economic Development and Trade and the Federal Agency for the Real Estate Cadastre, Moscow.

Gosudarstvennyi doklad o sostoianiiiispol'zovaniizemel' v rossiiskoifederatsii v 2006 godu. 2007. Ministry of Economic Development and Trade and the Federal Agency for the Real Estate Cadastre, Moscow. 
Gosudarstvennyi doklad o sostoianiiiispol'zovaniizemel' v rossiiskoifederatsii v 2007 godu. 2008. Ministry of Economic Development and the Federal Agency for the Real Estate Cadastre, Moscow.

Gosudarstvennyi doklad o sostoianiiiispol'zovaniizemel' $v$ rossiiskoifederatsii $v 2008$ godu. 2009. Ministry of Economic Development and the Federal Agency for the Real Estate Cadastre, Moscow.

Gosudarstvennyi doklad o sostoianiiiispol'zovaniizemel' v rossiiskoifederatsii v 2009 godu. 2010. Ministry of Economic Development and the Federal Service for State Registration, Cadastre, and Cartography, Moscow.

Gupta, Nandini, John Ham, and Jan Svejnar. 2008. Priorities and Sequencing in Privatization: Evidence from Czech Firm Panel Data. European Economic Review 52:183-208.

Heckman, James, Sergio Urzua, and Edward Vytlacil. 2006. Understanding Instrumental Variables in Models with Essential Heterogeneity. Review of Economics and Statistics 88:389-432.

Heller, Michael. 1998. The Tragedy of the Anticommons: Property in the Transition from Marx to Markets. Harvard Law Review 111:621-88.

Imbens, Guido, and Jeffrey Wooldridge. 2007. Instrumental Variables with Treatment Effect Heterogeneity: Local Average Treatment Effects. Paper presented at the National Bureau of Economic Research Summer Institute's What's New in Econometrics lecture 5, Cambridge, MA, July 3. http://www.nber.org/WNE/lect_5_late_fig.pdf.

Interfax. 2011. Glava assotsiatsii prompredpriatii Brianskoi oblasti obviniaet Rosimushchestvo v byurokratizme. February 14. http://www.interfax-russia.ru/Center/news.asp ?id $=210408 \& \mathrm{sec}=1679 \& \mathrm{p}=4$.

Johnson, Simon, John McMillan, and Christopher Woodruff. 2002. Property Rights and Finance. American Economic Review 92:1335-56.

Kaganova, Olga. 1998. Urban Real Estate Markets in Russia: The Current Stage. Real Estate Issues 23(2):30-35.

Khakhalin, Andrei, and William Pyle. 2009. The Perpetual Impermanence of Enterprise Land Reforms in Russia. Russian Analytical Digest 64:8-11.

Kisunko, Gregory, and Jacqueline Coolidge. 2007. Survey of Land and Real Estate Transactions in the Russian Federation: Statistical Analysis of Selected Hypotheses. Policy Research Working Paper No. 4115. World Bank, Washington, DC.

Krauth, Brian. 2011. Bounding a Linear Causal Effect Using Relative Correlation Restrictions. Unpublished manuscript. Simon Fraser University, Department of Economics, Burnaby, BC. http://www.sfu.ca/ bkrauth/papers/rcr.pdf.

Lewis, Bill, Alex Reznikovitch, Alexei Beltyukov, Denis Burgrov, Andrey Dutov, Andrei Kachoubski, Vadim Larine, et al. 1999. Unlocking Economic Growth in Russia. Report prepared by the McKinsey Global Institute, Washington, DC. http://www.mckinsey .com/insights/europe/unlocking_economic_growth_in_russia.

Limonov, Leonid, Nina Oding, and Tatyana Vlasova. 2001. Land Market Development in St. Petersburg: Conditions and Peculiarities. Paper presented at the Lincoln Institute of Land Policy conference, St. Petersburg, May 29-30.

Miranda, Alfonso, and Sophia Rabe-Hesketh. 2006. Maximum Likelihood Estimation of Endogenous Switching and Sample Selection Models for Binary, Ordinal, and Count Variables. Stata Journal 3:285-308.

Muir, Russell, and Xiaofang Shen. 2005. Land Markets: Promoting the Private Sector by Improving Access to Land. Public Policy for the Private Sector 300, October. World Bank, Washington, D.C. 
O’Leary, Sheila, and Olga Kaganova. 1997. Real Property and Land Legislation in the Russian Federation. Real Estate Issues 22(2):8-14.

Perotti, Enrico, and Stanislav Gelfer. 2001. Red Barons or Robber Barons? Governance and Investment in Russian Financial-Industrial Groups. European Economic Review 45:1601-17.

Remington, Thomas. 2002. Russia's Federal Assembly and the Land Code. East European Constitutional Review 3:99-104.

Soto, Hernando de. 2000. The Mystery of Capital: Why Capitalism Triumphs in the West and Fails Everywhere Else. New York: Basic Books.

Vasilieva, Yulia. 2011. Ne otdadim ni piadi: biznesu nuzhno vykpat' predpriatiami. Rossiiskkaia Biznes-Gazeta, September 27. http://www.rg.ru/2011/09/27/zemlya.html.

Woodruff, Christopher. 2001. Review of De Soto's The Mystery of Capital. Journal of Economic Literature 39:1215-23.

World Bank. 2006. Survey of Land and Real Estate Transactions in the Russian Federation: Cross-Regional Report. Washington, DC: World Bank. http://documents.worldbank.org/ curated/en/2006/03/6777488/survey-land-real-estate-transactions-russian-federation -vol-1-4-cross-regional-report.

Yel'kina, Vera. 2011. Veste' ne otdali zemliu pod zavodom. Newsler.ru, April 11. http:// www.newsler.ru/economics/2011/4/13/vesta.

Zhuravskaya, Ekaterina, Oleg Zamulin, Akhmed Akhmedov, Evgenii Yakovlev, and Oleg Schetinin. 2005. Monitoring the Administrative Barriers to Small Business Development in Russia: The Fifth Round. CEFIR Policy Paper 22. Center for Economic and Financial Research, Moscow. 